\title{
MIKA KARHU
}

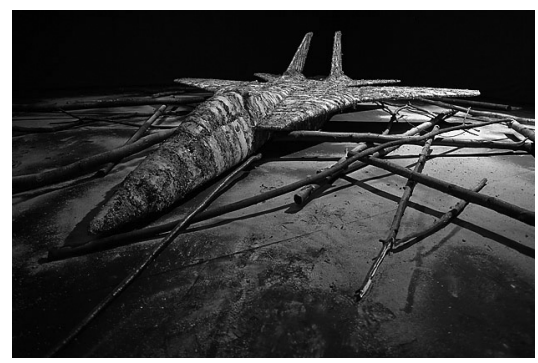

KAHDEN VALON VÄLISSÄ, 2013. INSTALLAATIO, YKSITYISKOHTA.

KOIVUTUOHI, JÄKÄLÄ, TUHKA, PUU, $60 \mathrm{M}^{2}$.

Mika Karhun (s. 1969) voimakkaat tussi- ja hiilipiirrokset tuntuvat nostavan esiin jokapäiväisen kokemuksen takana olevia varjoja - todennäköisesti painajaisia. Aiheet vaikuttavat ensi katsannolta selkeiltä, mutta ensivaikutelma on hälvenevää lajia: juuri kun jostakin on saanut kiinni se tuntuu muuttuvat joksikin lukuisista mahdollisista vastakohdistaan. Tämä Karhun teosten tulkinnallinen moniulotteisuus on johdonmukaisen työskentelyn tulos; sen osoittaa teossarja hänen kotisivuillaan [http://www.mikakarhu.com/teokset_kaikki.html].

Karhu on osallistunut lukuisiin yhteisnäyttelyihin vuodesta 1991 alkaen sekä Suomessa että esimerkiksi Skandinaviassa, Saksassa ja Brittein saarilla ja pitänyt 30 yksityisnäyttelyä vuodesta 1994 alkaen. Lisäksi hän on tehnyt videoteoksia sekä koonnut ja kuratoinut lukuisia näyttelyitä.

Karhu aloitti taideopintonsa 1980-luvun puolivälissä Pohjois-Karjalan käsi- ja taideteollisessa oppilaitoksessa ja jatkoi Hyvinkään taidekoulussa sekä Lahden taideinstituutin grafiikan osastolla. Hän valmistui taiteen maisteriksi Taideteollisessa korkeakoulussa (2000) ja suoritti taiteen tohtorin tutkinnon Aalto yliopiston taiteiden ja suunnittelun korkeakoulussa (2013). Karhun tohtorin tutkielma Taide sosiaalisen kokemuksen ilmaisuna. Taiteellis-teoreettinen tutkielma taiteen tekemisen läbtökobtiin ilmentää hänen pyrkimystään selkiyttää taiteen yhteiskunnallisia merkityksiä. Tutkimuksen taustalla on pragmatistinen filosofia."Pyrin luomaan mahdollisimman avoimen ja taiteen sisällöllisten yhteyksien johdonmukaiseen kuvaamiseen riittävän välineistön", totesi Karhu tutkielmansa tavoitteista.

Mika Karhun taiteellista otetta voisi luonnehtia termillä "teoreettinen käytännöllisyys". Sitä ilmentävät hänen toteuttamansa näyttelyprojektit sekä niiden tueksi kirjoittamansa tekstit (luettavissa kotisivuilla). Projektin Memory Traces (2006-2010, Koblenz ja Berliini) taustatekstissä "Muistin kerrokset" hän toteaa: "Muistin kerrokset, muistin painaumat ovat taiteen sosiaalista kokemusmateriaalia.[...] Taiteilija työskentelee sosiaalisen kokemuksen merkityksiä prosessoiden." Projektin Kipu (Keravan taidemuseo 2010) taustatekstissä"KIPU - näkökulmia kivun anatomiaan" hän analysoi kipua sekä yksilökohtaisena että sosiaalisena kokemuksena ja myös metaforana."Kivulla ei ole yhtä ilmiasua. Kivulla ja kärsimyksellä on yhtä monta kasvoa kuin sen kokijaa." Karhun kuratoima näyttely"Vieraantuminen"(Hyvinkään taidemuseo 2014) käsitteli kouluampumisia sekä ihmisten sosiaalista vieraantumista. 